\title{
Writing Place History, Living Place History: Dimensions of Student Learning in a Geomedia-based Holocaust Education Environment
}

\author{
Gl_Forum 2020, Issue 2 \\ Page: 55 - 67 \\ Full Paper \\ Corresponding Author: \\ tim.schoetz@stud.sbg.ac.at \\ DOI: 10.1553/giscience2020_02_s55
}

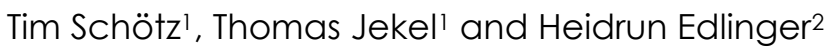 \\ 'University of Salzburg, Austria \\ ${ }^{2}$ AHS Heustadelgasse, Vienna, Austria
}

\begin{abstract}
As contemporary witnesses of the Holocaust in both family and institutional environments disappear, Holocaust Education has to deal with a radical change. A wide variety of digital, sometimes spatially-explicit, learning environments have been developed that could be called 'virtually interactive'. Only a few of these learning environments allow for researchbased learning, and even fewer have been evaluated according to the aims of Holocaust Education itself, or with regard to the digital tools used. This contribution presents central aspects of an evaluation of a research- and geomedia-based learning environment. It was tested with students at various schools in Vienna's second district, specifically in the Stuwerviertel, which was a place of widespread deportation during the Nazi regime. In this paper, we concentrate on three domains: (1) the usability of currently available tools, (2) the emotional side of the research-based learning process, and (3) the contributions of the learning environment to the formation of the political subject.
\end{abstract}

\section{Keywords:}

Holocaust Education, geomedia, collaborative mapping, places of remembrance

\section{Introduction: Current challenges in Holocaust Education and geomedia}

Coincidentally, the first day of our project (see section 2.) happened to be International Holocaust Remembrance Day. The Hashtag ‘\#Weremember’ was highly visible in social media. But such widespread awareness could give rise to questions of whom we remember and through which channels and media. These questions on remembrance culture are difficult to answer. Around the globe, there are different approaches to the topic. German memorial sites are described as neutral in tone and objectified (Yair, 2014), which has resulted in a more distant way of history telling. But an essential part of Holocaust Education (including education on other genocides) is the confrontation of emotions and a moral approach on the one hand, with historical correctness and understanding on the other (König, 1998). Looking into memorial and remembrance pedagogy in Yad Vashem (Israel's World Holocaust 
Remembrance Centre), one approach is to revive the stories of Holocaust victims from an autobiographical perspective (Mykayton, 2013).

Some 'key educational experiences' are missing in Holocaust remembrance culture (Yair, 2008, p. 92). Notably, interactive learning environments in German-speaking countries are lacking as an opportunity to encourage students' self-discovery. Researching and tracing the history of Jewish deportees in Vienna (Schötz, Jekel \& Wöhs, 2020) is one way of allowing students independently to discover the brutality of the Nazi regime, while at the same time questioning the circumstances and discourses leading to it.

Remembrance in educational terms often, if not always, deals with violent and unjust actions (Kansteiner, 2014). The aim of remembrance culture in an educational context is to challenge us emotionally as well as intellectually, to disturb our everyday routines, and to provide narratives of the past. In many cases, proponents aim to 'trigger self-critical reflections about humanity's predilection with self-destruction' (Kansteiner, 2014, p. 403). Current conditions lead - especially in the case of the Holocaust and Nazi terror - to the need to change Holocaust Education both in structure as well as in learning content and experience.

The role of the digital sphere in remembrance culture has been discussed in the literature for quite a while (see for example Geser, 1998; Hess, 2007; Levinger, 2009). The approaches very much reflect what was technically possible at a given time. The roles of digital (geo)media can be manifold, but a few stand out (see Jekel, Schötz \& Wöhs, 2020). Increasingly elaborate visualizations, and public, sometimes cartographic, access to databases have become the norm.

The implementation of (geo)media in Holocaust Education is not new (see Fitchett \& Good, 2012), but there are no data evaluating the use of geomedia in mapping, tracing and communicating about places of remembrance and genocide. We suggest that a geomedia-based approach to the Holocaust is more relevant than other action-oriented learning environments. One of our key areas of interest are the feelings of secondary-school students as they carry out projects that confront them with sites of the Holocaust, as these feelings may both enhance as well as hinder learning (see Hintermann, 2020). The level of emotionalization, however, is closely related to the appropriation of space, because of how students construct space through their own experiences (Tuan, 1977).

Current geomedia-supported tools for Holocaust Education include, but are not limited to (see Jekel, Schötz \& Wöhs, 2020):

1. Virtual reality tours of places of the Holocaust, often portraying concentration camps using aesthetics and rhetoric that can seem strange. For example, an Auschwitz virtual reality tour (BBC News, 2015) shows unpopulated spaces, with sedate music and very little text. These virtual realities (in our subjective reading of them) do little to foster remembrance of inhumanity, crime, torture and violence. Instead, they offer a distanced, peaceful impression of the places depicted. Emotionally, the depiction does not necessarily link to the historic events remembered at the specific places, and therefore probably does not support learning.

2. At the same time, holograms of survivors were developed, containing extensive interview material that can be used in educational contexts (Kansteiner, 2014; Zalewska, 2016; see also www.erinnern.at). For education and 'interactivity' purposes, these interviews can be divided into answers to hundreds of questions. These questions have to be formulated by learners or 
the general public, to generate the impression of interactivity and authenticity. While the activity can contribute to emotional effects, real interactivity with individuals who passed away a considerable time ago cannot of course be achieved, and the effect is very different from dealing with contemporary witnesses in the real sense (Bertram, 2015).

3. Last but not least, information technology has been used to create address-based databases of victims. A typical example is the Memento Vienna initiative, which also provides cartographic access to the wider public (Schellenbacher, 2017; see also www.memento.wien). Such initiatives are local, regional or national, and are not currently standardized. The European Holocaust Research Infrastructure (EHRI) is one of the driving forces in both integrating these databases with each other and exploring avenues for their use by the public in public spaces, and in education.

Whereas the hologram approach does not necessarily link into the idea of place-based learning, the other initiatives do. Places of remembrance, however, need to be experienced through all the senses, not audiovisual encounters alone (Hintermann, 2020). The individual exploring a specific place needs to be able to change the angle of view, to smell and feel, to link different aspects of the surroundings which are not available online in order to critically analyse its history. The concept we follow here combines experience of place and the construction of (mainly online) document-based research.

A coherent pedagogy using recent technological advances has still to be developed, but we strongly believe that using places of remembrance to support citizenship education can and will be supported through (geo)media. At the same time, we strongly support the view that an active physical encounter with a place and the traces of history inscribed in it is not to be missed. The real-world encounter allows for a completely different individual construction of that place, and for a variety of learning processes not possible through the sole use of technology, digitized historical sources and narratives. Accordingly, our project (described in Section 2) put this personal encounter with places of remembrance at the centre of the learning environment, with the paradigm of traces (Hard, 1995) being used to construct new places of remembrance. Digital geomedia provided support for finding and documenting locations, and for writing and publishing histories.

\section{Writing place history, Living place history: a geomedia and Wiki- based learning environment}

At the University of Vienna, all students training to become teachers in Geography and Economics have to participate in the University-Educational Cooperation Project (Vielhaber, 1998), which involves a learning environment that is quite different from the 'ordinary' classroom. Within a very generally-formulated topic, secondary-school students focus on a specific area they are interested in, with trainee teachers in an explicit support role to help them achieve their goals. At least part of the project has to be carried out beyond the school walls. Trainee teachers are typically responsible for two or three secondary-school students during the week-long project; the same trainees consider this course one of the most important 
experiences of their teacher training in Geography and Economics (source: trainee teachers and student grapevine).

In the project described, because of limits on the data available, topics (writing history through individual biographies) and places (the geographical area of the Stuwerviertel in Vienna's second district) were fixed, and individual deported persons were pre-selected based on recommendations of the DÖW (the Documentation Centre of Austrian Resistance).

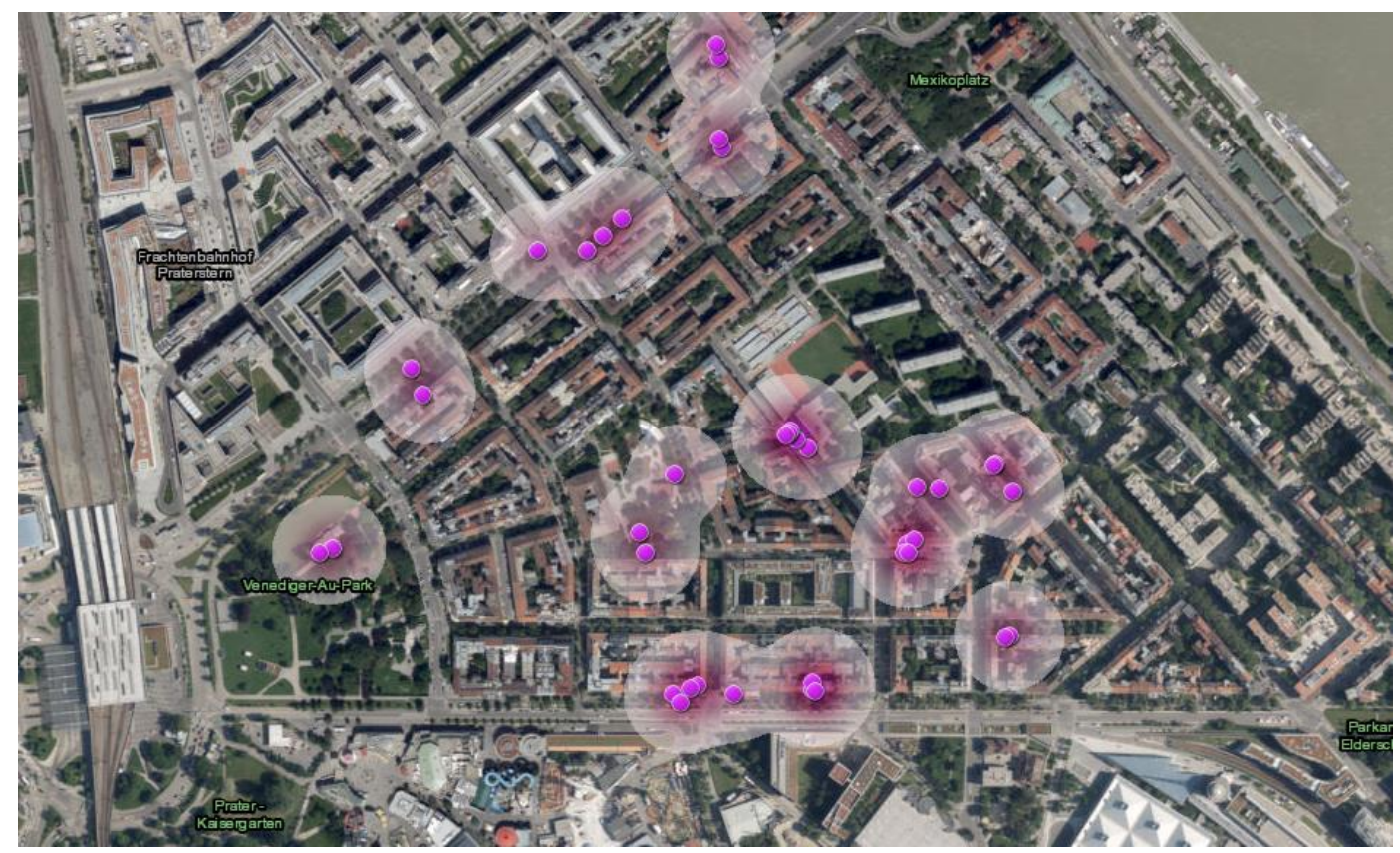

Figure 1: Map of the Stuwerviertel with the locations of traces of past Jewish life (students' work)

The Stuwerviertel (see Figure 1) was selected for several reasons:

- First, the area had a sizeable Jewish population pre-1938. Post WWII, the neighbourhood had a less savoury image, as it included a redlight district and rundown buildings. Currently, minor gentrification tendencies can be identified.

- Second, the area was less well travelled and documented by researchers than other parts of Vienna's second district, allowing students to devise a meaningful contribution.

- Third, the quarter is bordered by three main thoroughfares, is eminently reachable from school, and has light traffic, making it safer and more viable for a school project.

Secondary-school students were from two $6^{\text {th }}$ forms (age approx. 16 years) at the Gymnasium (AHS Heustadlgasse). According to the general curricula, they had at least 3 modules on history and political education: Fascism, nationalism and dictatorship; Holocaust / Shoah, genocide and human rights; and remembrance cultures and remembrance politics (all at the age of 14) (BGBI, 2016). Several general educational principles, none more so than the principle of 
citizenship education, also allow the inclusion of Holocaust-related topics in a range of other subjects (BMBF, 2015). In addition, there is constant media coverage of Holocaust-related subjects, which are strongly socially embedded, such that the effects of pre-concepts concerning the Holocaust are difficult to determine.

Most of the central research questions were developed by students in a 2-hour pre-project session through a moderated process. The session covered the major topics of identifying traces of Jewish culture in the neighbourhood today, as well as history / Living place history today. The final stages of reporting (a public presentation at the Museum of Vienna's second district) were again fixed, owing to rules of project work both at school and within the University-Educational Cooperation project (Vielhaber, 2003).

In the first phase, students wrote spatial and individual histories based on a single deported person from the neighbourhood. They used the Memento Vienna app (Schellenbacher, 2017) to find specific places of deportation and gather initial data, enriched this data by research using historical sources, then set about writing individual and georeferenced biographies for the Vienna Historical Wiki (see Figure 2; for the materials used, see Schötz, Jekel \& Wöhs, 2020). This first phase, which was designed for students to get a feeling for the spatial histories that are lived through today, was pre-set for them. Both the Memento Vienna app and the Vienna Historical Wiki are explicitly geo-referenced, supporting the aim of constructing individual places of remembrance.

Stuwerviertel - writing spatial histories, living spatial histories

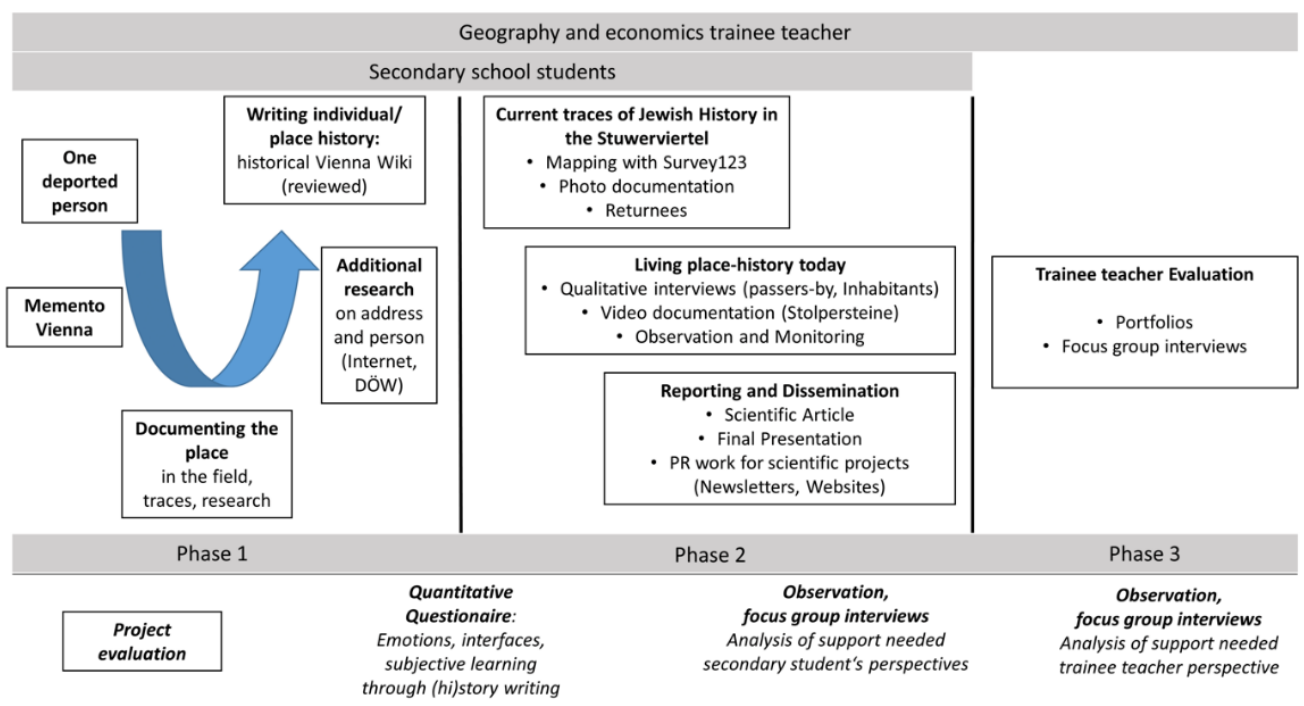

Figure 2: General Project Structure and Dimensions of Evaluation (based on Wöhs, Paulischin-Hovdar \& Gatterbaver, 2018, and Jekel, Schötz \& Wöhs, 2020). 


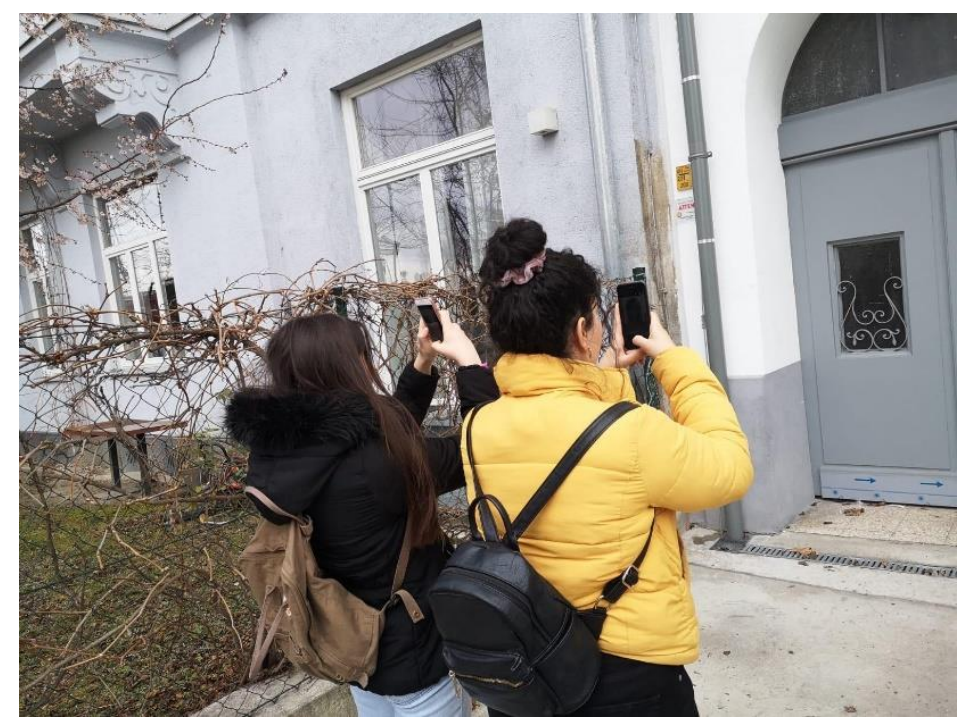

Figure 3: Secondary students doing field research, looking for traces on site

In the second phase, students attempted to answer their self-developed research questions, again using geomedia for documentation and analysis. It has to be stressed that the students' aim was to make histories accessible in the present and foreseeable futures. This phase also included writing a scientific report, preparing a final public presentation, and doing PR for the project in cooperation with project partners.

The third phase concerned trainee teachers only. It included their reporting and portfolios on the teaching and learning experience of the project, as well as an open discussion of improvements and additions that could be made to the learning environment.

\section{Evaluation of the project's learning environment - topics and methods}

Within the learning environment, a host of different aims were followed. These were derived from:

- questions concerning the user-friendliness of the technology,

- teaching experiences, gained during the pre-project, regarding the emotional sideeffects of place-based learning (Jekel, Schötz \& Wöhs, 2020),

- the general aims of Holocaust Education and Education for Spatial Citizenship

The evaluation of the approach was based on 46 students from secondary education and 17 students in teacher training. The school chosen was AHS Heustadelgasse in Vienna, in order to reduce the likelihood of students having prior knowledge of the research area. A mixedmethod approach (Creswell \& Clark, 2017) was used, combining a questionnaire with quantitative and qualitative questions, observation of student research and learning, and focus- 
group interviews. In addition, two teachers who had used this specific approach with classes gave their personal impressions of the learning processes with regard to individual secondary students. There were thus many perspectives on the project, allowing not only a triangulation of data sources but also validation of the different methods (Jick, 1979). The quantitative questions were evaluated using a six-point Likert scale (Likert, 1932) to check for tendencies. The qualitative questions and observations were interpreted using Mayring's (2010) inductive method.

The feasibility of using digital approaches to Holocaust Education (Vienna History Wiki and Memento Vienna) was evaluated in comparison to quantitative and qualitative questions formulated by the secondary-school students and the observations made by the students in teacher training.

Measuring the emotional effects of place-based learning, especially in the context of tracing the Jewish deportees' last homes, was preferred over a quantitative evaluation. We used a simplified version of Shaver, Schwartz, Kirson \& O'Connor's (1987) approaches to categorize four general emotions: surprise, anger, sadness and fear. In terms of the appropriation of space, these categories can be linked to the informative-significative everyday regionalization (Werlen, 1997, pp. 257 and 381-2; Schreiber, 2017).

To measure the impact of the project regarding the aims of Holocaust and citizenship education, the secondary-school students were asked qualitative questions about their learning success concerning the topic of the Holocaust itself and the digital media and tools.

\section{Results}

Quantitative and qualitative evaluation data were collected from 35 secondary-school students after the first phase of the project, i.e. after being confronted with the actual places of deportation and writing place-based Wiki entries.

Digital approaches to Holocaust Education, as used in the Vienna History Wiki, Memento Vienna and other online resources, were described mostly positively because of their accessibility and ease of use, fast and various research options, and because the 'internet never forgets' (student, female, 16) regarding the bios of the deported and murdered members of the Jewish population. Communication about places and sharing the history of the people who lived there is an essential part of Spatial Citizenship Education (Gryl \& Jekel, 2012), although some secondary students did mention that there was a lack of information and sources online and on site for the person they were examining.

The emotional side-effects of this approach to Holocaust Education were widespread. Many students reported high levels of 'surprise', mentioning the 'huge number of deaths' (student, male, 16) and 'how quickly people [the Jewish deportees] can be forgotten' (student, female, 16).

Mostly the students were shocked and horrified by the annihilation of so many Jewish families in Vienna, as seen in statements like how much the Nazi regime 'despised the Jewish people' 
(student, male, 16), or how 'this past was a really bad time' (student, female, 16) and 'happened here in Vienna' (student, male, 16).

Such reactions could denote a 'key educational experience' (Yair, 2008, p. 92) in Holocaust Education, because similar responses were obtained when the students were asked what they would 'never forget' about working on the project. The question regarding whether the students felt guilty (a sub-category of sadness) was based on the assumption of collective responsibility. However, they hardly showed any feelings of guilt. The result is similar to that for the group of trainee teachers. This relates to 'coming to terms with the past' ('Vergangenheitsbewältigung'; Maislinger, 2017) and the obligation to remember, and could furthermore correlate with the acceptance in Austria of the 'Opfermythos' ('Austria victim theory', denoting a post-WWII discourse defining Austria as the first victim of Nazi Germany) (Uhl, 2001), but it could also be the result of increasing historical distance from the events concerned.

Students also felt very little sadness, fear or pain. The cross-item correlation shows that this was because of the lack of personal biographical information and traces for some of the deportees. Student groups with sufficient data showed a higher emotional response. It is this emotional response that needs to be transferred to today's discourse and political structures (Lutz, 2013).

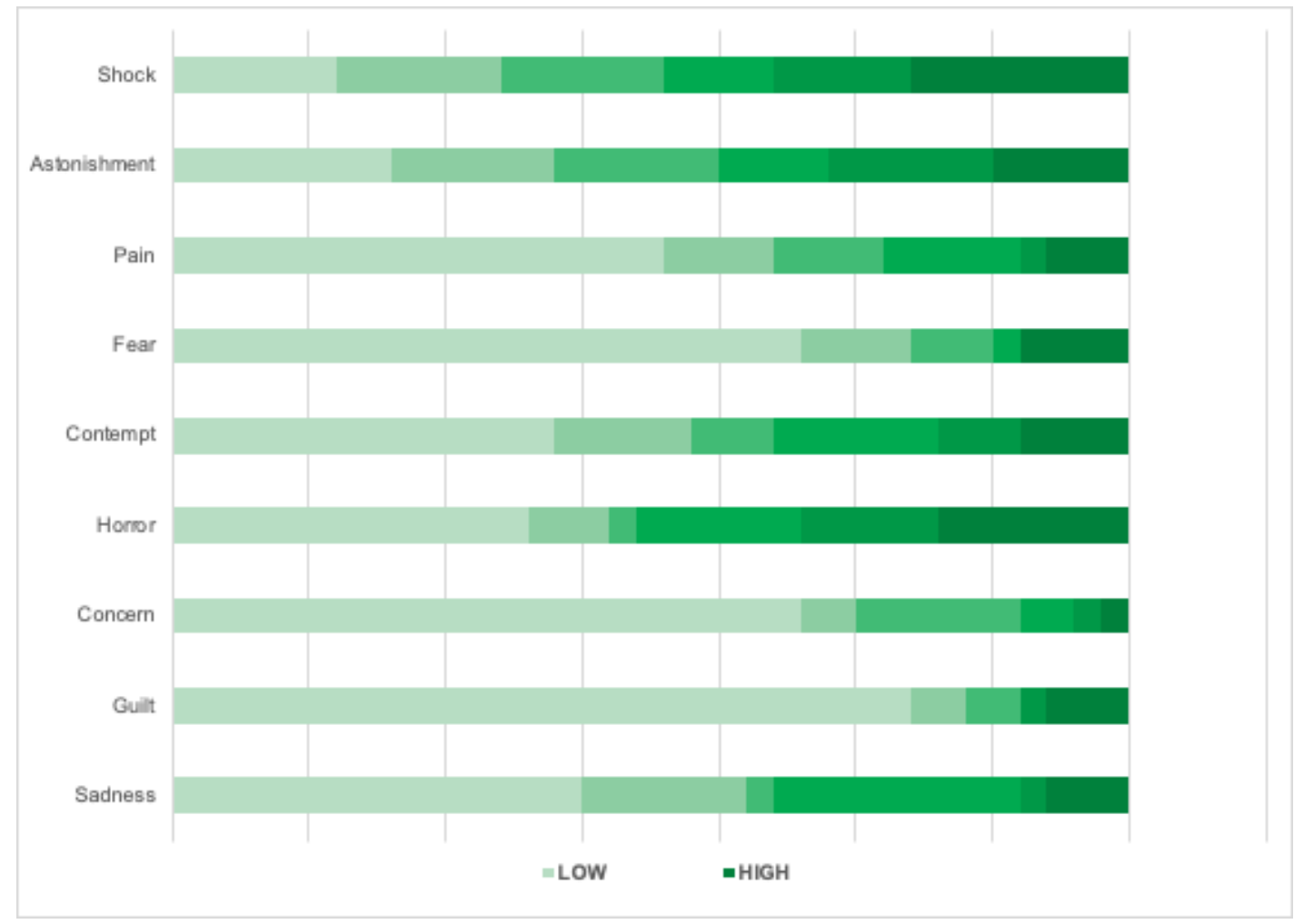

Figure 4: Emotions of secondary-school students experienced while working on the project; $n=35$ (authors' own Figure). 
The significance of Holocaust Education (see Eckmann, 2010; Metthes \& Meilhammer, 2015) for Spatial Citizenship Education (see Jekel, Gryl \& Donert, 2010; Gryl \& Jekel, 2012) was reflected in the students' qualitative answers. Mostly, students said that it is important to prevent such inhuman behaviour (e.g. genocides) and pointed to the extreme brutality ('it was really brutal' (student, female, 15). For the students, the Holocaust is an essential part of Austrian history. Communicating about the Holocaust is therefore an important task, especially for remembering its victims and bringing their stories back to life, as illustrated by this comment: '[This project] was quite cool and it is a nice feeling to participate in the remembrance of people' (student, male, 16). Interestingly, some students were able to instantly link their research work to current discourses characterized by xenophobia and exclusion with regard to specific groups. Overall, the students thought that the part they played in researching, writing and sharing their stories was essential for the remembrance of the Holocaust.

The trainee teachers $(\mathrm{n}=8)$ showed a slightly different picture regarding emotions while working on the project. Because of their age and prior knowledge of the subject, they were less surprised by the facts of the Holocaust. However, they were similarly shocked and horrified by people's personal stories. This also showed in relation to sadness: students who had found too little information on site and online felt less connection to the person and were therefore not as sad. But as one trainee teacher (female, 22) stated, 'To find nothing is also an important discovery.'

Like the pupils, the student teachers were positive about the accessibility, participatory possibilities, and possibilities for communicating and disseminating information in this mainly digital project. The search for the last places of residence was also given great importance as an empathic but also cognitive-visual approach to Holocaust Education.

The focus-group interviews and the comments of the trainee teachers accompanying the secondary-school students showed further qualitative findings. The focus groups clearly demonstrated that searching for traces on site is of great importance for the project, and memories would be less vivid without this excursion-like approach. As in Schreiber (2017), the identification of the last places of residence of the deportees in combination with the written background information and pictures has contributed to the fact that space no longer represents a purely physical-material construct, but acquires much more significance (Tuan, 1977) and symbolism. Unfortunately, the hoped-for creation of emotions of sadness could not be demonstrated in some groups due to the lack of available traces on site. Pupils were very horrified and shocked as a result of visiting actual locations of deportations. However, the project also showed that the understanding of space by considering the present and past contributes to the initiation of an historical orientation competence (Schreiber, 1997).

Communication about and remembering the places and victims of the Holocaust, and thus the (re-)visualization of stories, were accorded a very high priority in this project. With regard to the education of students as global citizens in view of the Third Reich's injustice and cruelty of dealing with the Jewish population and other minorities, such priorities could result in more tolerant, respectful and anti-racist citizens (UNESCO, 2017). This also shows the potential of Spatial Citizenship approaches in connection with Holocaust Education.

In summary, the overall picture of the emotional focus of the project and the associated challenges is extremely broad, but the project, which was also presented in this form in the 
district museum at Leopoldstadt, has been very well received by all participants and viewers. The challenges of this learning environment are strongly connected (including in relation to the emotional and empathetic part of Holocaust Education) with the existing information and the information uncovered about the deported Jewish people, or its lack. But not finding traces also means something for the state of the culture of remembrance in the Stuwerviertel. As one student put it: 'I am fascinated how little there was to fascinate me' (student, male, 17), meaning that very few traces were easily visible in the Stuwerviertel area of Vienna.

The focus-group interviews and the evaluation showed that the geomedial and excursion-like aspects of the project had a great influence on students' understanding, participation and motivation, and on the achievement of learning objectives. Although there were no major emotional debates on the topic, far-reaching successes were achieved: the students remembered the Holocaust, researching and writing stories of the victims and their last places of residence in the Stuwerviertel, before sharing them with the world.

\section{(3) Else Breiner}

Else Breiner, * 11. Oktober 1886 Prossnitz (Mähren), † Riga.

\section{Biografie}

Else Breiner wurde am 11. Oktober 1886 in Prossnitz (Mähren) als Elsa Breinerová geboren. Bis 1938 wohnte sie in Wien 2, Reichsbrückenstraße 40 (heute: Lassallestraße). Laut Bescheid der Stadt Wien, Magistratsabteilung 21, Abteilung 1 vom 25. Juni 1938 wurde ihre Gemeindewohnung mit 31. Juli 1938 gekündigt. Ihre letzte bekannte Wohnadresse war in Brünn, Křenová 79.

Am 5. Dezember 1941 wurde sie von einer Sammelstelle in einem Schulgebäude in Brünn, Merthautovstraße 37 zuerst mit dem Zugtransporter K, Nr. 200 nach Bohusovice transportiert und schließlich in das Konzentrationslager Theresienstadt deportiert. Die letzten drei Kilometer in das Konzentrationslager musste sie zu Fuß zurücklegen. Am 15. Jänner 1942 wurde sie mit dem Transportzug P, Nr. 597 nach Riga, im heutigen Lettland, weitertransportiert, wo sie ermordet wurde.

\section{Quellen}

- Holocaust.cz: Elsa Breinerová [Stand: 29.01.2020]

- Memento Wien: Else Breiner [Stand: 29.01.2020]

- Yad Vashem: Elsa Breiner [Stand: 29.01.2020]

- Yad Vashem: Transport K [Stand: 29.01.2020]

\section{Literatur}

- Wolfgang Scheffler / Diana Schulle (Hg.): Buch der Erinnerung: Die ins Baltikum deportierten deutschen, österreichischen und tschechoslowakischen Juden. Hg. vom Volksbund Deutsche Kriegsgräberfürsorge e.V. / RigaKomitee der deutschen Städte. Band 1. Berlin: Walter de Gruyter 2011, S. 497 [Stand: 29.01.2020]

\section{$f$ tellen}

\section{$8^{++1}$}

Figure 5: Published Wiki entry for Else Breiner (student work)

\section{Outlook}

While the project was considered successful by both the students and the teachers, and contributed to the work of social scientists and historians, quite a few open ends remain. 
The first is technical in nature and concerns the quality of the Wiki entries made by secondary students. In terms of content, they were considered acceptable by the historians responsible for curating the Wiki. However, their style and syntax had to be edited by professionals. Here, better preparation of students might help. At the same time, the curation by professionals is of course essential due to the sensitivity of the topic. Because of the timeframe of the current project, but also because of the timeframe of school projects in general, the need for professional editing may make the project unusable as a citizen science approach.

The second major topic regards emotions at places of remembrance and any effect on learning that these may have. While we had hoped to show a positive correlation between personal confrontation with this difficult topic (supported by geomedia), emotions and motivation, individual effects could not be traced by the methodology used. Research into this issue would probably need further orientation from psychology and learning theory and is reserved for future projects.

Nevertheless, we do believe that the approach is transferable, in terms of space as well as of the historical period, and suggest that other project-based teaching may make use of the general concept.

\section{Acknowledgements}

Thanks are due first and foremost to the students participating in the project and positively supporting us with their ideas and insights. Further thanks go to Wolfgang Schellenbacher (DÖW Vienna) who helped us with data on deported persons, and to Susanne Pils (Vienna City Archive) and Evelyne Ruef (Vienna Library) for supporting the Vienna Historical Wikiend of the project with their reviewing and useful tips.

\section{References}

BBC News. (2015, January 27th). Auschwitz: Drone video of Nazi concentration camp - BBC News [Video File]. Retrieved from https://www.youtube.com/watch?v=449ZOWbUkf0

Bertram, C. (2015). Lebendige Erinnerung oder Erinnerungskonserven und ihre Wirksamkeit im Hinblick auf historisches Lernen. Zeitschrift für Biographieforschung und Oral History 28, 178-99.

BGBI. Nr. 88/1985. (2016): Semestrierter Lehrplan. Retrieved from https://www.ris.bka.gv.at/Dokumente/Bundesnormen/ NOR40201120/NOR40201120.pdf

Bundesministerium für Bildung und Frauen (BMBF, 2015): Unterrichtsprinzip Politische Bildung, Grundsatzerlass. Retrieved from https://www.bmb.gv.at/ministerium/rs/2015_12. pdf?515357

Creswell, J. W., \& Clark, V. L. P. (2017). Designing and conducting mixed methods research. Sage publications.

Eckmann, M. (2010). Exploring the relevance of Holocaust education for human rights education. Prospects 40, 7-16.

Elwood, S. \& Mitchell, K. (2013). Another Politics Is Possible: Neogeographies, Visual Spatial Tactics, and Political Formation. Cartographica 48, 275-92.

Fitchett, P. G. \& J. A. Good (2012). Teaching Genocide through GIS: A Transformative Approach. In: The Clearing House: A Journal of Educational Strategies, Issues and Ideas 85, 87-92. DOI: 10.1080/00098655.2011.628713 
Geser, H. (1998). Auf dem Weg zur Neuerfindung der politischen Öffentlichkeit. Zürich.

Gordon, E., Elwood, S. \& Mitchell, K. (2016). Critical Spatial Learning: Participatory Mapping, Spatial Histories, and Youth Civic Engagement. Children's Geographies 14, 558-72.

Gryl, I., \& Jekel, T. (2012). Re-centring geoinformation in secondary education: toward a spatial citizenship approach. Cartographica 47(1), 18-28.

Hard, G. (1995). Spuren und Spurenleser. Zur Theorie und Ästhetik des Spurenlesens in der Vegetation und anderswo. In: J. Deiters, G. Hard, N. de Lange, W. Lückenga, H-C. Poeschel, D. Stonjek \& H. J. Wenzel (Hrsg.) Osnabrücker Studien zur Geographie 16. Rasch: Osnabrück.

Hess, A. (2007), Digital remembrance: vernacular memory and the rhetorical construction of web memorials. Media, Culture \& Society, 29(5), 812-30.

Hintermann, C. (2020). Erinnerung - Bildung - Raum: Erinnerungs- und Gedächtnisorte als Lernimpulse für einen politisch bildenden GW-Unterricht. GW-Unterricht 157(1), 5-18.

Jekel, T., Gryl, I. \& Donert, K. (2010). Spatial Citizenship. Beiträge von Geoinformation zu einer mündigen Raumaneignung. Geographie und Schule 32, 39-45.

Jekel, T., Lehner, M., Vogler R. (2017). Mapping the Far Right: Geomedia in an Educational Response to Right-Wing Extremism. International Journal of Geoinformation 294, 1-14.

Jekel, T., Schötz, T., \& Wöhs, K. (2020). Remembrance, Space, Education. Emancipatory and Activist Approaches through (Geo-)media. In G. O'Reilly (Hrsg.), Places of Memory and Legacies - In an Age of Insecurities and Globalization. Basel: Springer. Pages pending

Jick, T. D. (1979). Mixing qualitative and quantitative methods: Triangulation in action. Administrative Science Quarterly, 24(4), 602-11.

Kansteiner, W. (2014). Genocide memory, digital cultures, and the aesthetization of violence. Memory Studies, 7(4), 403-08.

König, H. (1998). Pädagogisches Moralisieren nach Auschwitz: Tiefenhermeneutische Rekonstruktion der in einer Sozialkundestunde mit einer Zeitzeugin zutage tretenden Professionalisierungsdefizite. In: Henkenborg, P. \& H. W. Kuhn (Hrsg.): Der alltägliche Politikunterricht: Ansätze - Beispiele Perspektiven qualitativer Unterrichtsforschung zur politischen Bildung in der Schule, 135-49. Wiesbaden: VS Verlag.

Levinger, M. (2009). Geographical Information Systems Technology as a Tool for Genocide Prevention: The Case of Darfur. Space and Polity 13, 69-76.

Likert, R. (1932). A technique for the measurement of attitudes. Archives of Psychology 22(140), 1-55.

Lutz, T. (2013). Lernorte Gedenkstätte und zeithistorisches Museum. In: Handbuch Nationalsozialismus und Holocaust. Historisch-politisches Lernen in Schule, außerschulischer Bildung und Lehrerbildung 66, 367-82.

Maislinger, A. (2017). Coming to terms with the past: An international comparison. Nationalism, Ethnicity, and Identity, 169-76.

Mayring, P. (2010). Qualitative Inhaltsanalyse. In: Günter, M. \& K. Mruck (Hrsg.). Handbuch qualitative Forschung in der Psychologie, 601-13. Wiesbaden: VS Verlag.

Metthes, E. \& Meilhammer, E. (2015). Holocaust Education im 21. Jahrhundert/Holocaust Education in the 21 st Century. Bad Heilbrunn: Klinkhard.

Mkayton, N. (2013). Der Holocaust in jüdischer Erinnerungskultur und Pädagogik - am Beispiel Yad Vashem. Erinnerungskulturen, 113-25.

Schellenbacher, W. (2017). Memento Vienna: A Case Study in Digital Archives, Georeferenced Data and Holocaust Education. GI_Forum 2, 13-22.

Schötz, T., Jekel, T., \& Wöhs, K. (2020). RaumGeschichten schreiben. SchülerInnen

erforschen den Holocaust in Wien. GW-Unterricht 157 (1), 45-55.

Schreiber, W. (1998). Geschichte vor Ort. Versuch einer Typologie historischer Exkursionen. In: Schönemann, B., Uffelmann, U. \& Voit, H. (Hrsg.). Geschichtsbewusstsein und Methoden historischen Lernens, 213-26. 
Schreiber, W. (2017). Raum - vernachlässigte Kategorie der Geschichtskultur. Zeitschrift für Geschichtsdidaktik 16, 48-66.

Shaver, P., Schwartz, J., Kirson, D., \& O'Connor, C. (1987). Emotion knowledge: further exploration of a prototype approach. Journal of personality and social psychology 52(6), 1061.

Tuan, Y. F. (1977). Space and Place. The Perspective of Experience. Minneapolis: University of Minnesota Press.

Uhl, H. (2001). Das „erste Opfer“. Der österreichische Opfermythos und seine Transformationen in der zweiten Republik. Home 30(1), 19-34.

UNESCO (2017). Education about the Holocaust and preventing genocide. Paris: UNESCO. Retrieved from https://unesdoc.unesco.org/ark:/48223/pf0000248071

Vielhaber, Christian (1998). Universitär-schulische Kooperationsprojekte. Ein fachdidaktisches und schulpraktisches Ausbildungsangebot am Institut für Geographie der Universität Wien. In: DiemWille \& Thonhauser: Innovationen in der universitären Lehrerbildung, 199-216.

Vielhaber, C. (2003). Projektunterricht auf dem Prüfstand: Wann ist ein „Projekt“ ein Projekt? 12 Fragen zur Absicherung. GW-Unterricht 90, 57-63.

Werlen, B. (1997), Sozialgeographie alltäglicher Regionalisierungen. Globalisierung Region \& Regionalisierung. Stuttgart: Franz Steiner Verlag.

Wöhs, K., Paulischin-Hovdar, R. \& Gatterbauer, A. (2018). Fostering Holocaust Education and Remembrance Culture using Geomedia. GI_Forum 6, 193-206.

Yair, G. (2008). Key educational experiences and self-discovery in higher education. Teaching and Teacher Education 24(1), 92-103.

Yair, G. (2014). Neutrality, Objectivity, and Dissociation: Cultural Trauma and Educational Messages in German Holocaust Memorial Sites and Documentation Centers. Holocaust \& Genocide Studies 28,510 .

Zalewska. M. (2016), Holography, Historical indexality and the Holocaust. In: Misra, S. \& Zalewska, M. (Eds). Technologies of Knowing. Spectator 36(1), 25-32. 